合）の掲げた，電気自動車用電池に関する中長期開発目 標を Table 3 に示す ${ }^{2)}$. 今回開発した大形りチゥムイ オン二次電池は, USABC の掲げる中期目標を十分満 足するものである.

以上，リチウムイオン二次電池が，特性面において電 気自動車用電池として可能性があり，有望であることを 示した。しかしながら，実用面においてはまだ課題が残 されている，その課題とはコストと安全性である。特に コストについては，高いコスト比率を占めるリチウム酸 コバルトなどの電池構成材料の見直しが必要である，今 後の実用化に向け，コスト，安全性及びさらなる特性向
上に努力していきたい．

実車試験結果は，日墥自動車㑣殿からの提供資料に基 づくあのであり，同社技術車両開発室川原崎主担; 同, 宮本主查; 同社総合研究所, 社会・商品研究所, 任田主 担に謝辞を呈する。

\section{文献}

1）園部，96 バッテリー技術シンポジウム要旨集，日本能率 協会 (1996).

2) USABC, Electric Vehicle Battery Test Procedure Manual, July (1994).

\title{
Q4 電気自動車用固体高分子型燃料電池
}

\section{光田憲 朗}

\section{1 はじめに}

固体高分子型燃料電池 (PEFC) は, 室温からの動作 が可能で, 高い出力密度が得られ, しかもバッテリーと 異なり充電が不要で，ガソリン車のように燃料を補給し て連続して走行できるので，電気自動車用の電源として 期待されており，米国のエネルギー省（DOE），日本の 新エネルギー・産業技術総合開発機構 (NEDO) や, カナダのBPS 社, 米国のゼネラルモータース社, ドイ ッのシーメンス社, ダイムラーベンッ社, 日本のトヨタ など国内外で開発が進められている.

PEFC の動作原理や国内外の開発状況については, 本誌に扔いても，1993年11月号の電気自動車特集で詳

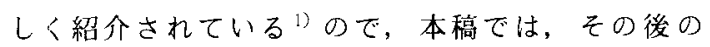
PEFC の電気自動車用への適用例やメタノール燃料の 場合の開発課題, メ夕ノール直接型 PEFC の開発状況, PEFC 電気自動車の市場への導入予測などについて紹 介する.

\section{2 高圧水素を燃料とする PEFC 電気自動車}

高压水素を燃料とする $\mathrm{PEFC}$ 電気自動車は, BPS 社 の $200 \mathrm{~kW}$ のバスやダイムラーベンッの $50 \mathrm{~kW}$ の自動 車などが試作され，運転試験されている。

Fig. 1 は, BPS 社の $200 \mathrm{~kW}$ のバスの外観写真であ り, 後部下側にトータル $200 \mathrm{~kW} の$ PEFC スタックが, また天井部分に軽量压力容器に収められた高圧水素ボン ベが配置されている.

Fig. 2 は, BPS 社の $200 \mathrm{~kW}$ のバスの後部下側の拡

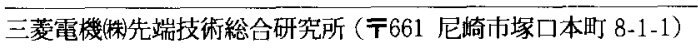

大写真であり，もともと 275 馬力（約 $200 \mathrm{kW）のディー}$

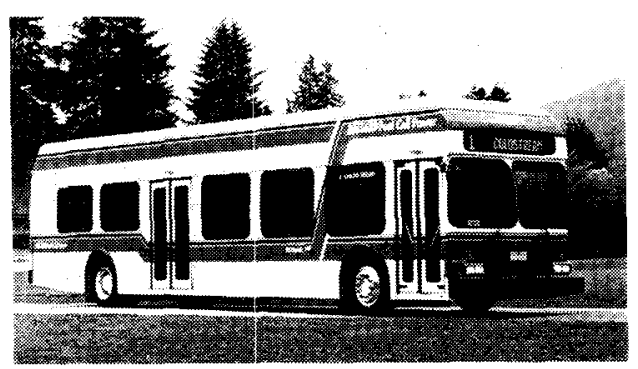

Fig. 1 Photograph of the Ballard's phase 2 PEFC bus.

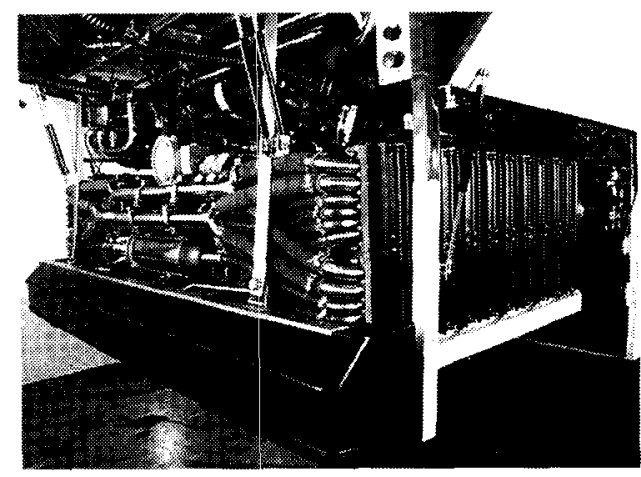

Fig. 2 Photograph of the stacks of the PEFC bus. 
ゼルエンジンが収められた部分にすっぽりと $200 \mathrm{~kW} \mathrm{の}$ $\mathrm{PEFC}$ スタックが収まっている. PEFC スタックは 10 $\mathrm{kW}$ 級のむのが 22 個使用されている。このバスは 1 [回] の水素充填で約 $400 \mathrm{~km}$ の走行が可能であり, 水力発電 の電力の豊富な力ナダでは，水電解によって水素を製造 し，それまでのロータリーバスの代わりに PEFC 電気 バスを走行させる計画が進められている。

$\cdots$, 高圧水素を燃料とする $\mathrm{PEFC}$ 電気自動車の普

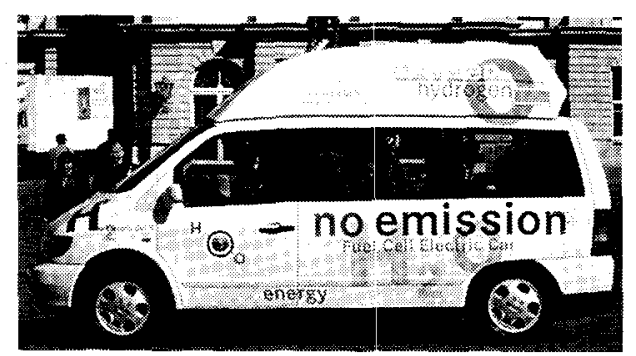

Fig. 3 Photograph of the Daimler-Benz NECAR II fuel cell vehicle.

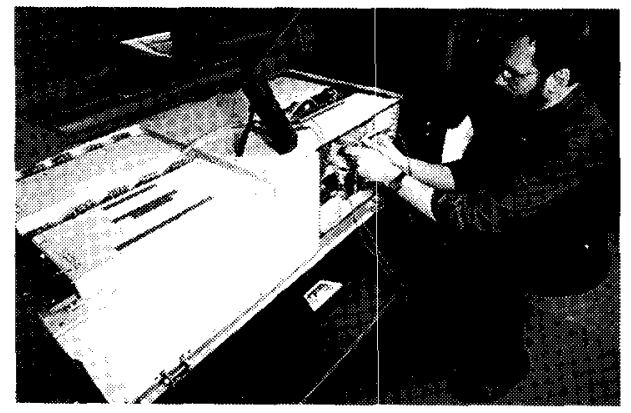

Fig. 4 Photograph of the stacks of the NECAR II.

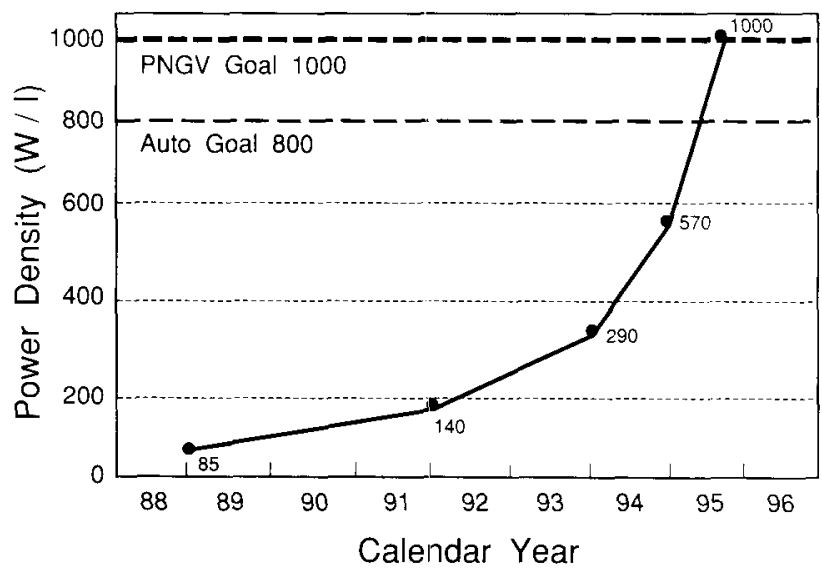

Fig. 5 Chart of power density of Ballard stacks against year.
通乗用車への適用については，芳から自動車の燃料とし ての純水素利用に積極的なダイムラーベンッが BPS 社 之共同開発を進めており，96 年5月にNECAR I （Fig. 3）を発表している.

NECAR II後部の PEFC スタック部分の应大図を Fig. 4 に示す. わずか 2 つのスタックで $50 \mathrm{~kW}$ を出力 しており，大幅に高出力密度化が進められている。1つ のスタックには150セルが積層されており,トータルの 直流電圧は $180 \mathrm{~V} \sim 280 \mathrm{~V}$ で，ス夕ック重量は $6 \mathrm{~kg} /$ $\mathrm{kW}$ である。燃料となる高压水素は，PEFC 電気バス の場合と同梯に天井部分の軽量死力容器（カーボンファ イバー強化プラスチック）に収められている。航続距離 は $250 \mathrm{~km}$ で, 6 人乗り, 最高速度は $110 \mathrm{~km} / \mathrm{h}$ である. スタックの高電流密度化のために，スタックの徹底した コンパクト化が図られている。

BPS 社のスタックのコンパクト化の歴史（Fig.5)

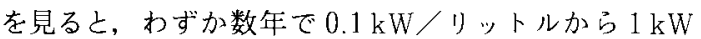
イリットルへの高密度化を実現していることがわかって いる.

Fig.6は，NECARIに用いられていると思われる BPS 社スタックの外観図である ${ }^{2)}$ ，反応がスや泠却水 を流すための内部マニホールドは反応面積部分の外周部 分に配置されるのが一般的であるが，Fig.6の場合に は中央付近の 6 筒所の穴に配置されている，また，ス夕ッ クに面圧をかけるための押え機構も外周部尔ではなく内 部マニホールドの内部に配置され，押えバネや反応ガス の出入口が全て押え板の内部に収納されている．従って スタックの外周部は全て反応部分でガスシール部分が最 小限にされているなど，みごとなまでに徹底したコンパ クト化が行なわれていることが分かる。

さらに，表裏に反応ガス流路を有するカーボン製のセ パレー夕についても，従来カーボン製の平板の表裹に機 械加工によって反応ガス流路が形成されていた むのが䏽張黒鉛のモールド加工などによって反 庍ガス流路や内部マニホールドを含めて一挙に 成型することにより低コスト化を図ると共に, 厚みも従来よりもかなり薄く作られているよう である、薄肉化に伴って反応がス流路の断面積 あ小さくなっているので, 反応がスの入口と出 口の差厈が大きくなっており，常圧での運転は 難しいかも知れないが，少なくと䯩压水素を 用いての加压運転には最適な構造と思われる.

な㧍，加圧運転では，加圧空気を供給するた めに空気コンプレッサーが用いられるので，大 きな補機動力を必要するが，補機動力をできる だけ回収するためにエキスパンダー（膨張機） が用いられて晾り，高圧水菜の王力あ補機動力 の回収に利用可能である。 


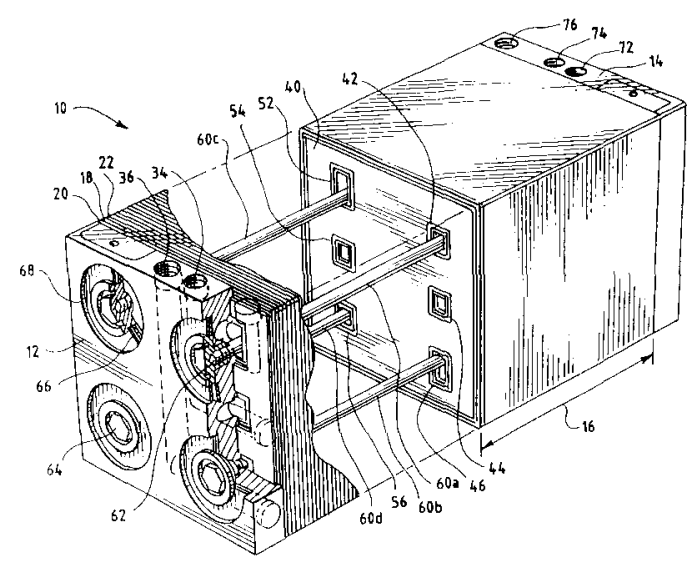

Fig. 6 A perspective view of a high power density type Ballard's stack. (P. Gibb et al. ${ }^{2)}$ )

以上のように，高生水素を燃料とする PEFC 電気自 動車は，すでに実用化可能な段階に達している．残念な がらまだ水素のインフラが整備されておらず，現段階で の普及は用途的にも地域的にも限られたものにならざる を得ない，しかし，将来水素燃料が一般的になれば，高 圧水素を然料とする PEFC 電気自動車がガソリン車や ディーゼル車に替わって大采車となる可能性むある.

\section{3 メタノールを燃料とする PEFC 電気自動車}

自動車の然料としては,ガソリン, 軽油の他に, メ夕 ノ一ル, エタノール, メタン, プロパン，ブタンなよ゙が 考えられ，PEFCを用いると内燃機関に比べて発電効 率が高くなると共に, $\mathrm{HC}, \mathrm{NO}_{\mathrm{x}}, \mathrm{CO}$ な゙の排出量が ほとんよ゙なくなる。しかし PEFCの場合，これらの燃 料を水蒸気改質によって水素を主成分上する改質ガスに 变換する必要がある。しかも改質温度が $300^{\circ} \mathrm{C}$ 前後のメ夕ノール以外は改質温度が $600^{\circ} \mathrm{C}$ 以上 と高い.また，メタン，プロパン，ブタンなよ゙ は改質反応を阻害する付臭剤が含まれており， 完全に取り除く必要がある、メ夕ノ一ルはエネ ルギー密度がガソリンの約半分と低いが，ガン リンと同様に液体で給油できること，天然ガス から容易に合成できることなどから，PEFC 電気自動車に最も適した燃料と考えられる.

常压動作メ夕ノール燃料の PEFC の一般的 なシステムフロー図をFig. 7 に示す.メタノー ル改質器では燃料電池で発生した生成水を用い, 燃料電池で使い残した燃料ガスと空気を触媒燃 焼させて改質を行う。

メタノールを燃料とする PEFC 電気自動車 については，米国では，DOE計画を中心に盛 んに研究が進められている. DOE 計画には,
米国の GM 社, カナダの BPS 社, ロスアラモス国立研 究所などが参画しており，第 1 フェーズのメ夕ノール改 質PEFC $10 \mathrm{~kW}$ 級システムのブレッドボードテストが 終了して,メタノール㳊質数十 $\mathrm{kW}$ 級 $\mathrm{PEFC}$ の車載を めざした研究が進められている. しかしまだ,メ夕ノー ルを燃料として PEFC 電気自動車が走行したという報 告はない。これは，まだ解決すべき大きな技術的課題が いくつか残っているからである。主な課題としては，第 1 にアノード (然料極) の CO 被毒対策, 第 2 に負荷変 動対策, 第 3 に頻繁な起動停止対策などが挙げられる.

まず第 1 の課題であるアノードのCO被毒対策につい てであるが，PEFCのアノードには白金系の触媒が用 いられていおり, 室温から $80^{\circ} \mathrm{C}$ 程度で動作されるので, 改質ガスに微量含まれるCOが白金粒子に強く吸着して 水素の還元反応を阻害するいわゆる CO 被毒が起こり， セル電圧が著しく低下する，白金触媒だけだと p p m オー ダーの COでもセル電玨が低下することが確認されてお り，CO 濃度を下げることと，アノードの耐 $\mathrm{CO}$ 被毒性 能を向上させることが必要である，選択酸化による $\mathrm{CO}$ 濃度低減や Pt-Ru 系合金による耐 CO 被毒性能の向上, 然料ガスへの微量の空気添加などの対策が報告されてい るが，決定的な対策にはなっていないのが現状で，CO 被毒対策は依然として最も大きな技術課題である.

次に第 20 課題である觼荷変動対策についてであるが, 普通乗用車では定地走行時には $10 \mathrm{~kW}$ もあれば十分走 れるが，追い越し加速時などには $100 \mathrm{~kW}$ 近くの出力を 必要とする. また負荷变動が極めて大きく, しかも変動 の予测が難しい，PEFC を車載する場合，高王水素を 燃料とした場合には負荷に応じて水素供給量と空気供給 量を加減することで負荷変動対策が可能である。しかし メタノール燃料の場合. 改質器でのメタノール改質能力

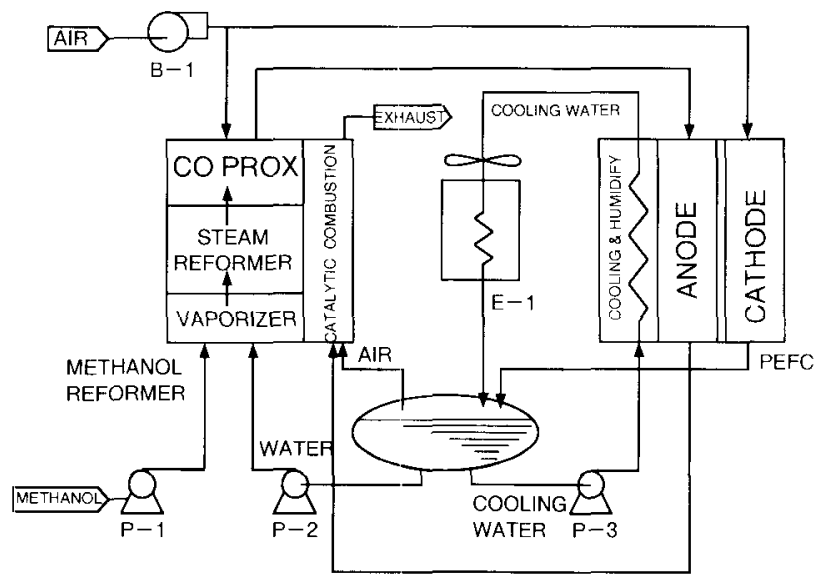

Fig. 7 Schematic of the metahnol fueled PEFC power generation systems. 
には限界があって，速い負荷变動に応じて改質量を加减 することは極めて困難である，そして，発電量に見合う 水素がアノードに供給されない場合には，アノードに用 いられているカーボンが腐食し，PEFCの寿命に影響 する，従って，PEFCはべース負荷を受け持って，変 動の激しい部分はバッテリー，ウルトラキャパシターや フライホイールなどを用い，その充放電て賄うなどの対 策が必要である. Fig. 8 は, メ夕ノール改質 PEFC 上 バッテリーを普通乗用車に車載した場合の想像図で，負 荷変動対策のためのバッテリーがかなりの容積を占める ことになる。

最後に第 3 の課題である頻繁な起動停止対策について であるが，現在のガッリン車は，キーのオン，オフで瞬 時に起動停止ができるので，メタノールを燃料とする $\mathrm{PEFC}$ 電気自動車でむ同様の機能が要求される. 高圧
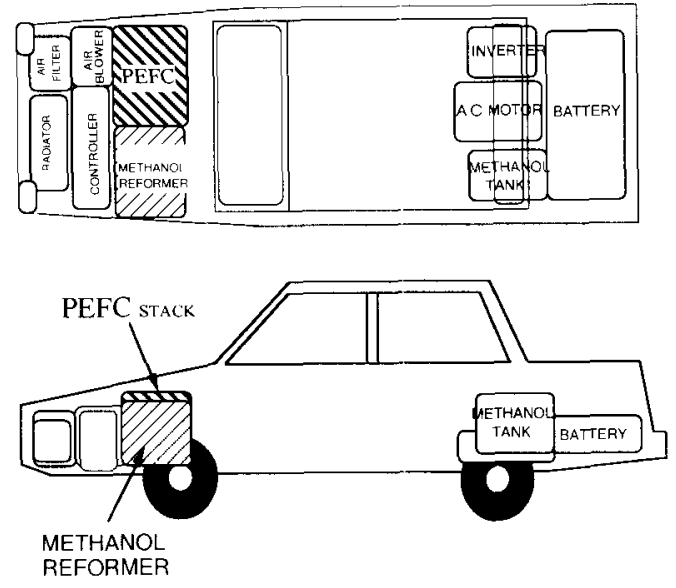

Fig. 8 Conceptional drawing of a PEFC/battery hybrid EV.

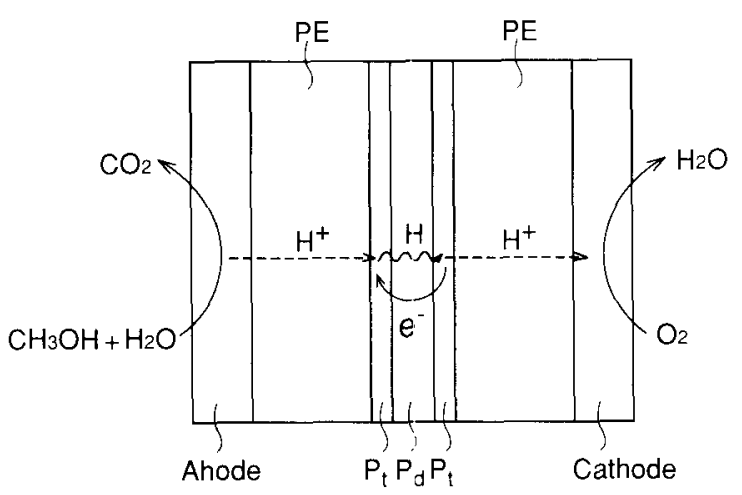

Fig. 9 Composite electrolyte system containing the methanol impermeable protonic conductor. (C. Pu et al. ${ }^{3)}$ )
水素を燃料とした場合には現在であ頻繁な起動停止は可 能であるが, メ夕ノール改質の場合， $300^{\circ} \mathrm{C}$ 前後の改質 温度をいかに保つかが課題である。また，頻繁な起動停 止に対する PEFC スタックやメタノール改質器の寿命 の確保も重要な課題である.

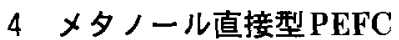

メ夕ノール直接型の燃料電池（DMFC）は，以前硫 酸型燃料電池などを用いて検討されたことがあるが最近 PEFC を用いた DMFC の研究が特に欧米で活発化し ている.これは, DMFCの場合は改質器が不要になり, 負荷变動に対する応答性が大幅に改善されるなど自動車 用電源としての魅力が一層高まるためと思われる，しか

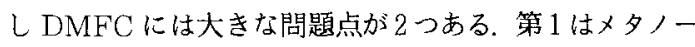
ルが固体高分子膜を通過してカソードに達し，直接酸化 されてしまう現象で，第2はメ夕ノ一ルのアノードでの 酸化反応の活性が低いこよである。

Fig. 9 は第 1 の問題点についての刘策例についての 模式図で，固体高分子膜内部に $\mathrm{Pt} / \mathrm{Pd} / \mathrm{Pt}$ のサンドイッ チ層を設けてメタノールの透過を防止する方法である ${ }^{3)}$. この他，固体高分子膜自身のメ夕ノール透過性を減少さ せる試みす行われている。

また，ロスアラモス国立研究所のグループはアノード 触媒に Pt-Ru 系を用い, 触媒層を極めて薄くし，さら に動作温度を $100^{\circ} \mathrm{C}$ 以上上げることで，メ夕ノール酸 化の活性が上がり，カッードへの透過も少なくなって， 高い出力密度が得られると報告している ${ }^{4)}$. ただ, 現在 の使用されている固体高分子膜は $130^{\circ} \mathrm{C}$ を超元ると柔ら かくなってクリープするので, 動作温度については,

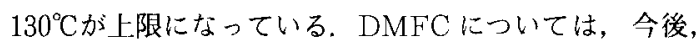
有効なメタノール透過の防止策と，アノ一ド触媒の改善， 動作温度の高温化が可能になれば, 可般電源や電気自動 車用電源への適用が一挙に進む可能性がある.

\section{PEFC 電気自動車の市場導入予測}

メタノールを燃料とする PEFC 電気自動車がま だ世の中に出てきていないので, PEFC 電気自動 車の市場導入予測を行なうことは難しいが，DOE の資料 ${ }^{5)}$ にバッテリー単独電気自動車，ハイブリッ ド電気自動車と共に PEFC 電気自動車の市場導入 予測（Fig. 10）が報告されており，当面，充電が 不要なハイブリッド電気自動車が主流で, PEFC 電気自動車が市場にでてくるのは 2007 年ごろと予 測されている。 バッテリー単独電気自動車は早くか ら市場に出ているが, 充電が必要で走行距離に限り があるために米国での市場は一般大衆車には広がら ず，バッテリーとガソリンエンジンあるいは, バッ テリーとディーゼルエンジンといったハイブリッド 
電気自動車が主流になると思われる.

従ってPEFC は八イブリッド電気自動車に使われて いるガソリンエンジンあるいはディーゼルエンジンの代 わりに用いられて市場に導入されると予想される。しか し, PEFC の負荷変動対策なよ゙の技術課題が解決され た場合や、メタノール直接型PEFC が開発された場合 には, PEFC 単独のメ夕ノール燃料電気自動車が大衆 車として受け入れられる可能性がある.

\section{6 おわりに}

PEFC 電気自動車は, 高圧水素を燃料とする場合に

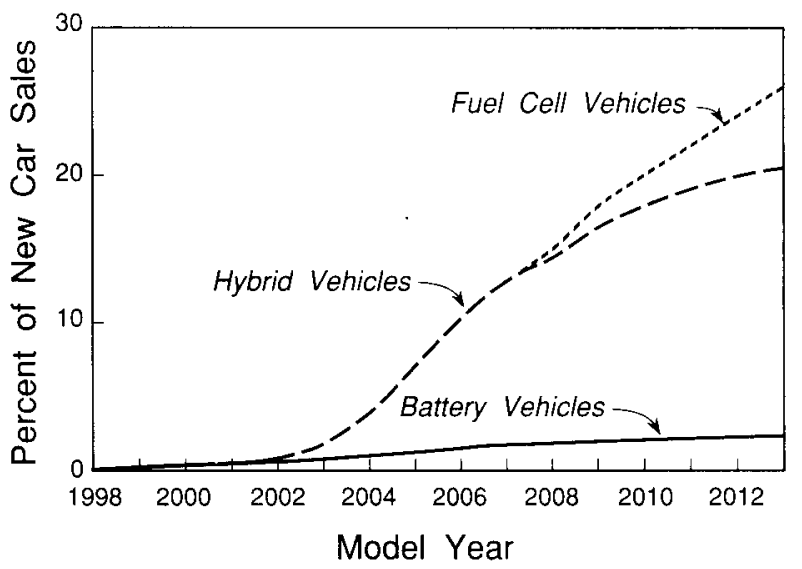

Fig. 10 Market penetration of battery EV, HEV and fuel cell vehicle. (A. R. Landgrebe et al. ${ }^{5)}$ )
は，ガソリンエンジンやディーゼルエンジンに対して見 少りしないほどの出力密度が得られており，すでに奉用 化可能なレベルにある上思われる，一方，広く大衆車之 して受け入れられる可能性のあるメタノールを燃料とす る PEFC 電気自動車については，まだ困難な技術課題 が残っており，開発はまだまだこれからである。しかし 脱石油燃料としてメタノールを用いた PEFC 電気自動 車はインパクトが大きく，産官学共同による PEFC 技 術開発の進展之技術課題の早期解決が望まれる.

最後に，貴重な写具や資料を提供していただいた BPS 社の Kenneth Dirks 氏とメルセデス・ベンッ日 本の秋山由紀子氏に謝意を表する。

\section{文献}

1) 山本 修, 高柳文成, 電気化学, 61, p.1258 (1993).

2) P. Gibb, H. H. Voss, W. Schlosser and E. G. Pow, USP 5, 484, 666 (1996).

3) C. Pu, W. Huang, K. L. Ley and E.S. Smotkin, J. Electrochem. Soc., 142, L 119 (1995).

4) X. Ren, M.S. Wilson and S. Gottesfeld, J. Electrochem. Soc., 143, L 12 (1996).

5) A. R. Landgrebe, J. Milliken and I. Weinstock, Automotive Technology Development Contractors's Coordination Meeting Oct. 23 (1995).

\section{「ショートレビュー」原稿募集のご楟内}

ショートレビュー欄ではいろいろな分野での最新の研究の動向を紹介していただいております。 特に若い方々からの投稿に支えられ，読者の皆様の御好評を得ていると伺っております．この 欄がさらに充実しますよう, 皆様のさらなるご協力をいただきたく，ここに原稿の募集をご案 内申し上げます。

○内 容 分野は問いません，過去何年かのペーパーやパテントを要領よくまとめたあの，ト ピックスの紹介的なものなどを公平な立場でお書き下さい.

○執筆の要領 原稿はそのままオフセット印刷されます. A 4 判用紬に 1 ページ，ワープロで お作り下さい，前の投稿例を参考にして下さい。

○送付先・連絡先 編集委員会「読物」係（下100 東京都干代田区有楽町 1-12-1 新有楽町 ビル $\mathbf{8 0 3 - 3 2 1 4 - 6 0 0 1 , ~ F A X ~ 0 3 - 3 2 8 7 - 0 0 3 7 ) ~}$

なお，掲載の可否につきましては編集委員会で決定させていただき訪すのでご了承下さい. 